\title{
sumergida en la tina
}

pienso en tu novia de juventud

muerta en el incendio

me secas el pelo con la toalla de tu hijo

que no conozco

recargas la cabeza en el borde

cerca de mi pecho

así se consuelan las visitas

junto a las camas de los enfermos

no dejo de mirar mis dedos pálidos

la piel les queda grande como un guante

como si algo la estuviera

derritiendo

anoche vimos las grietas en el techo

por primera vez

pensamos cualquier día

se nos cae encima

grietas luminosas se intuían

cada día de tormenta

pero no quisimos pensar en eso

anoche la habitación hacía silencio

como un bote hace agua

pensamos son las grietas en el techo

nuestras grietas pensamos

arriba algo crujió 